\title{
Design and Implementation of Tourism Information System in Ciletuh-Palabuhanratu Geoparks
}

\author{
Finsa NURPANDI ${ }^{1}$, Siti NAZILAH ${ }^{2}$, and Fietri Setiawati SULAEMAN ${ }^{3}$
}

\author{
Ifinsa@unsur.ac.id, Informatics Engineering Program, Suryakancana University, Cianjur, Indonesia \\ ${ }^{2}$ zilah.nazilah@gmail.com, Informatics Engineering Program, Suryakancana University, Cianjur, Indonesia \\ ${ }^{3}$ fietrift@unsur.ac.id, Informatics Engineering Program, Suryakancana University, Cianjur, Indonesia
}

\begin{abstract}
Ciletuh-Palabuhanratu UNESCO Global Geoparks is a single and unified geographical area the site and landscape are united with international geological significance managed with the concept of holistic protection, education and sustainable development. There are many sites located in the CiletuhPalabuhanratu Geoparks, so it becomes a major problem for tourists to found information about site to visited. This paper proposed design and implementation of tourism information system using Google Maps. The system based on Web-GIS, using Codeigniter framework, Google Maps API, AJAX, jQuery and so on. By using this system, tourists can find out the site locations and have a reference to plan their trip.

Keywords: Ciletuh-Palabuhanratu UNESCO Global Geoparks, tourism information system, Web-GIS,
\end{abstract}

Google Maps

\section{INTRODUCTION}

Ciletuh-Palabuhanratu UNESCO Global Geoparks (UGGp) is located on the island of Java and belongs to the administrative region of Sukabumi Regency. CiletuhPalabuhanratu UGGp has an area of 126.100 Ha or 1.261 $\mathrm{Km}$ which covers 74 villages located in eight subdistricts nameli Ciracap, Surade, Ciemas, Waluran, Simpenan, Palabuhanratu, Cikakak, and Cisolok [1]. CiletuhPalabuhanratu UGGp is divided into three geoarea, namely Ciletuh Geoarea, Simpenan Geoarea and Cisolok Geoarea. Ciletuh Geoarea has a landscape in the form of a horseshoeshaped plateau (amphitheater) that opens towards the Ciletuh Bay. This amphitheater has a diameter of more than $15 \mathrm{~km}$, so it is believed to be the largest natural amphitheater in Indonesia. In the middle of the amphitheater is the oldest rock distribution in West Java in the form of Bancuh and Opholite rocks deposited from collision activity between oceanic crust and continental crust in the Cretaceous Period, more than 65 million years ago. Ciletuh-Palabuhanratu UGGp is a tourism location with geological diversity such as waterfalls, landscapes, small islands, unique rocks, sea caves, beaches and geysers. Ciletuh-Palabuhanratu UGGp has become the main attraction of tourism in West Java in the past year since it was inaugurated by UNESCO in 2018 [2]. The tourism category in Ciletuh-Palabuhanratu UGGp is divided into seven categories, including waterfalls, landscapes, small islands, unique / aesthetic rocks, sea caves, beaches, and geysers.

Lack of information about the location of available tourism sites is a major problem for tourists in planning their trips. For some tourists, making reasonable travel plans is a major concern. In planning his trip, tourists need accurate information about the tourist sites that will be visited. Some tourists will search for information via the internet, but there are some disadvantages when searching for information via search websites such as [3]:

(1) Tourism information is scattered
It is very difficult to classify information obtained from search websites, so tourists need additional time to compile that information.

(2) Tourism information is unconfirmed It is very difficult to determine whether the information that appears on the search website is true and validated.

(3) Tourism information is flat

Most of the information that appears on search websites is a simple text description, not many that show pictures of the condition of tourism locations.

This paper proposed an idea to build a tourism information system using technologies of Web-GIS and Google Map. This system is intended for tourists who are interested in exploring tourism in Ciletuh-Palabuhanratu UGGp.

\section{LITERATURE REVIEW}

There are few studies related to the tourism information system, among others are: in the study of Veky A.B Hanas, Alb. Joko Santoso and Sutoyo they present a web-based tourism information system specifically for Rote Ndao District. Tourism information system that is designed as a means of tourism promotion in the area. information presented in the system includes services about profiles, news, tourist attractions, charm, events, accommodation services, maps, and bank data [4].

Li Pei and Zhu Chun-Hua in their research made a tourism information system application based on Windows Phone specifically for China's Xinzheng region. The system provides positioning services to obtain information about attractions, determine locations, and develop tourist routes [5]. Juin-Ling Tseng, Yan-Yi Jiang, Sheng-Jun Peng, and Hsiao-En Wei present a tourism information system with a different model, because its development uses Virtual Reality technology [6]. Xie Hongyong and Shi Xi in their research proposed a tourism information system framework based on geographic information systems (GIS) 
[7]. While Yimeng Wu, Zhixue Liang, and Liming Liu present the results of their research on a tourism information system based on the Google Maps API [3].

\section{ANALYSIS OF SYSTEM}

This research was conducted to answer several questions regarding the problems found as follow:

(1) How do tourists find general information about Ciletuh-Palabuhanratu UGGp?

(2) How do tourists know all the tourist sites in Ciletuh-Palabuhanratu UGGp?

(3) How can tourists be directed towards the tourist location to be addressed in the CiletuhPalabuhanratu UGGp region?

Functional requirements are an explanation of the system services that must be available, how the system must react to various inputs and how the system must run in a number of situations [8]. The following is a functional requirement of the tourism information system in CiletuhPalabuhanratu UGGp:

(1) Users can access general information from Ciletuh-Palabuhanratu UGGp starting from the profile, description, area coverage, and so on.

(2) Users can access tourism locations in the CiletuhPalabuhanratu UGGp area through the digital maps that have been provided, along with additional information from these locations. Like, descriptions, photos, and so on.

(3) Users can search for tourist locations in the Ciletuh Geopark, can be by category or not.

(4) Users can find out the route to the tourist destination in the Ciletuh Geopark area.

System users consist of guest and administrator. use case is used to describe the whole system as below.

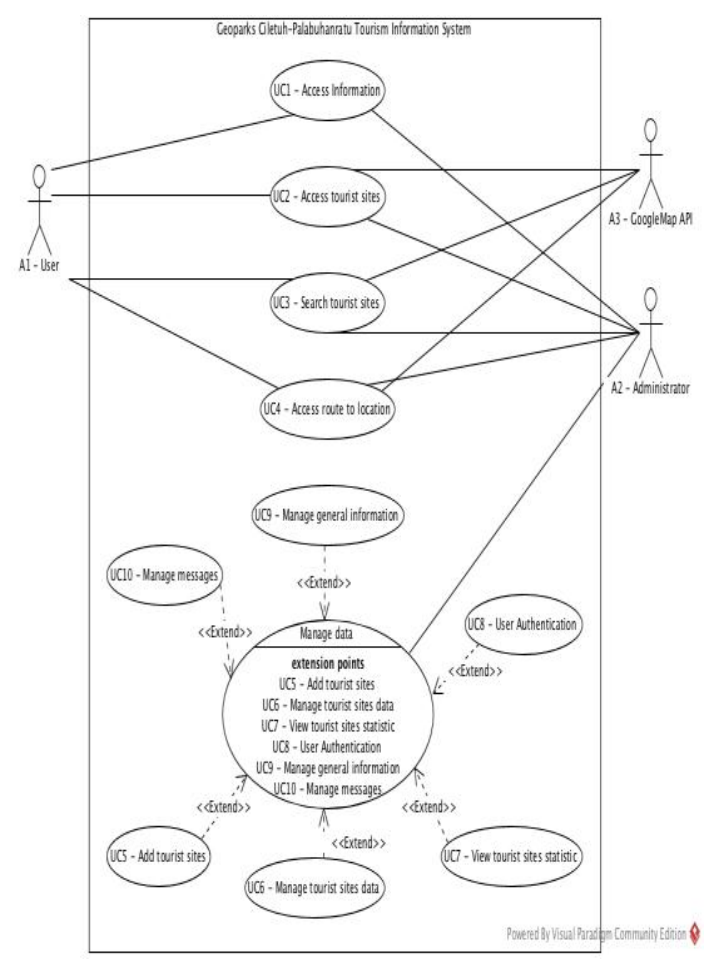

Figure 1. Use case Diagram

\section{DESIGN OF SYSTEM}

(1) Architecture Design of System

The tourism information system is adopted tree-layer architecture which includes presentation layer, logic layer, and data layer. Presentation layer is related to user interaction, how clients make requests to the system and get responses from the system as requested. The logic layer contains the system process for handling all client requests. On this system, Asyncronous Javascript and XML as we know as AJAX have a big role to play. All client requests are handled by AJAX, AJAX retrieves data from the database according to the client's request, then spatial data is sent to the Google Maps API to get the appropriate map. After receiving a response from the Google Map API, using AJAX's Document Object Model (DOM) sends the response results to the interface. So that changing data on the interface does not require reloading the page. Data layer on this system uses MySQL database. The architecture system is shown in Fig 2.

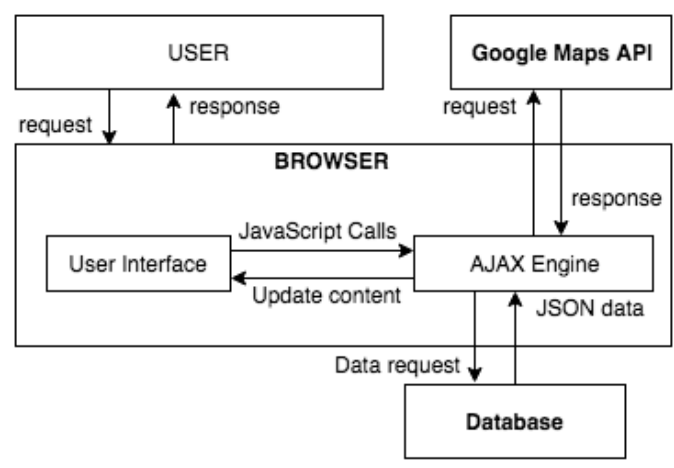

Figure 2. Architecture Diagram

(2) Class Diagram

In object-oriented programming, software systems are described in classes. Classes do not stand alone, but interact with other classes and groups of classes that collaborate with each other can be seen in class diagrams [9]. The following below is a Class Diagram for the CiletuhPalabuhanratu UGGp tourism information system using the MVC (Model View Controller) concept.

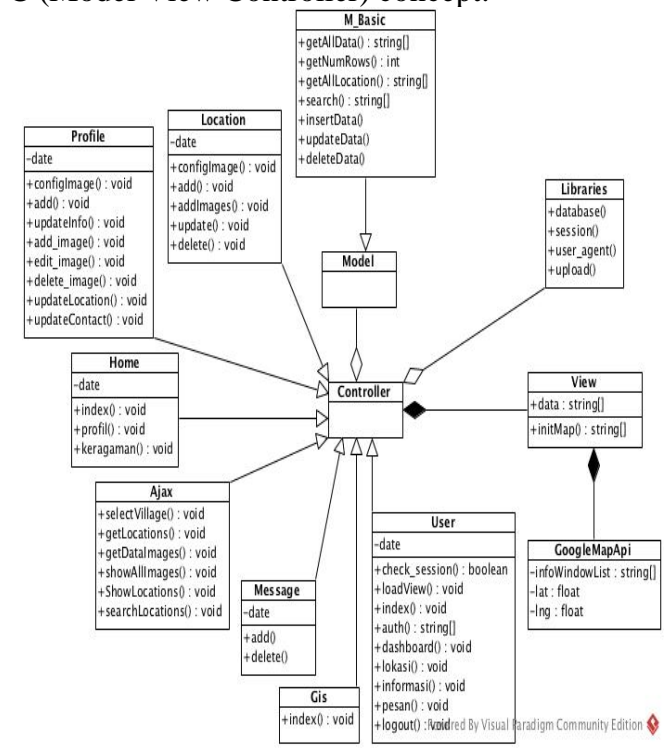

Figure 3. Class Diagram 
(3) Database Design

The Entity Relationship Model (ERM) describes data as entities, relationships, and attributes. The main concept explained by ERM is an entity, which is something or object in the real world that can stand alone. Each entity has an attribute that is a property to describe the entity. The relationship of each entity along with the attributes that exist in the database can be displayed with a graphical notation called the Entity Relationship Diagram (ERD) [10]. ERD tourism information system CiletuhPalabuhanratu UGGp is shown in Fig 4.

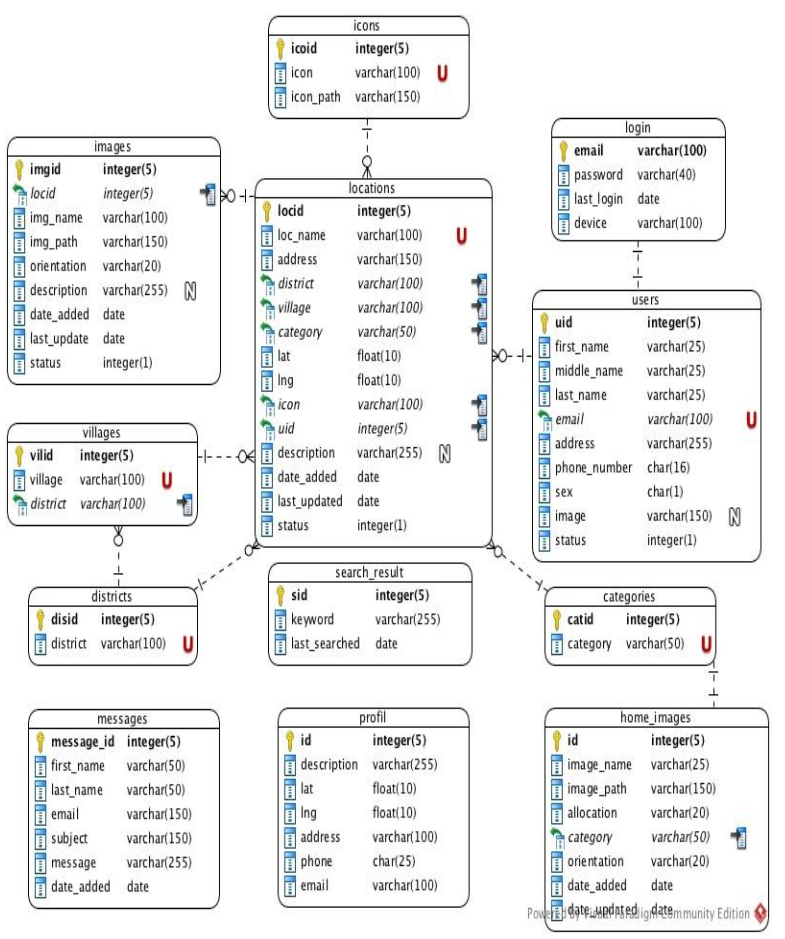

Figure 4. Entity Relationship Diagram

\section{IMPLEMENTATION}

(1) Map based service Google Map API

Google Map API is programming interface which is developed and provide by Google Company. The API lets user to customize maps with system content for display on web pages. There are several stages in using the Google Map API to be implemented in developing the tourism information system.

(1.1) Embedding Google Map into Web page

Tourism information system provides tourism locations based on predetermined categories such as waterfalls, landscapes, small islands, unique / aesthetic rocks, sea caves, beaches and geysers. In order to display a map, there are three important things that a map can display. First, create a map style using CSS. Second, create a map container using the id "map". Third, load the Maps API use a script tag. See Google Map API documentation to display map to a web page using Google Map API [11].

(1.2) Initializing Google Map

In this process provides a function to use the Google Maps API and display the map. See Google Map API documentation to display map to a web page using Google Map API [11].

\section{(1.3) Marking in Google Map}

Markers function to give a sign at a location on the map. In the tourism information system, it does not use a single marker but can display all of the tourist sites with markers. See Google Map API documentation to add Google Map with marker to a web pages [11].

(2) Technology of AJAX

AJAX technology can make requests to the server on the client-side. With this, the web page does not need to reload the page to update content. With AJAX, users would never know that anything was even transmitted to the server. In the tourism information system, every marker is loaded using AJAX. So, the markers that appear are in accordance with the travel category chosen by the user.

(3) Interface

The tourism information system interface is divided into two sections based on the information displayed namely text-based information and map-based information. In Fig. 5 on point (a), (b), and (c) are the system interface displays text-based information. Fig 5 on point (d) is an interface that displays map-based information. System interface as below:

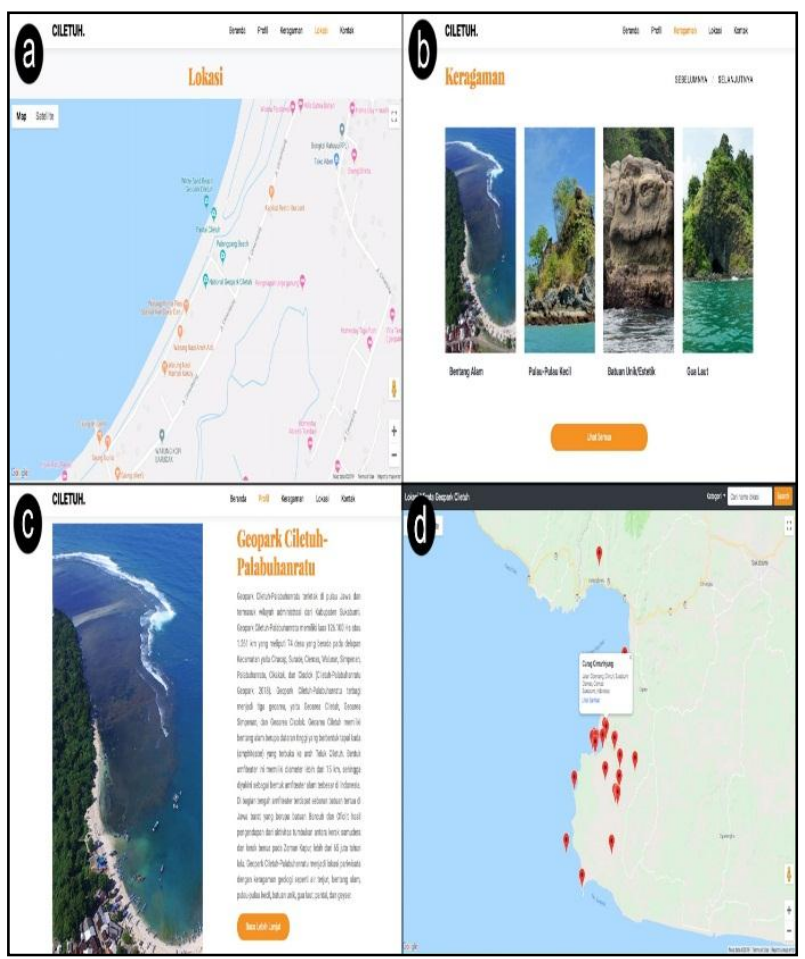

Figure 5. Interface System: (a) location map service, (b) Category services, (c) profile services, (d) GIS interface

\section{SUMMARY}

Tourism information system has been developed using Web-GIS technology with Google Maps as its basic map. By using this system, tourists who will visit to CiletuhPalabuhanratu UGGp can have sufficient references to plan their trip. Not only displaying text-based information, the system provides information in the form of pictures of the conditions of a tourist location in Ciletuh-Palabuhanratu UGGp. 
based on Windows phone," Proc. - 2011 Int. Conf. Inf. Technol. Comput. Eng. Manag. Sci. ICM 2011, vol. 1, pp. 398-400, 2011.

This research was financially supported by the Kemenristekdikti. The authors would like to express appreciation to colleagues for their support giving criticism, suggestions, and other help in the research process.

\section{REFERENCES}

[1] Ciletuh-Palabuhanratu Organization, "Geopark Ciletuh-Palabuhanratu,” 2018. .

\section{[2] UNESCO, "UNESCO Global Geoparks,"} 2017. [Online]. Available: http://www.unesco.org/new/en/naturalsciences/environment/earth-sciences/unesco-globalgeoparks/. [Accessed: 14-Aug-2018].

[3] Y. Wu, Z. Liang, and L. Liu, "Design and implementation of tourism information system based on Google Maps API," Int. Conf. Geoinformatics, 2013.

[4] V. A. B. Hanas, A. J. Santoso, and Suyoto, "Analysis and design of tourism information system: A study of rote ndao Indonesia," Proc. - 2017 2nd Int. Conf. Inf. Technol. Inf. Syst. Electr. Eng. ICITISEE 2017, vol. 2018-January, pp. 126-131, 2018.

[5] P. Li and C. H. Zhu, "Design and implementation of the tourism information system
[6] J. L. Tseng, Y. Y. Jiang, S. J. Peng, and H. E. Wei, "Development of intelligent tourism information system based on virtual reality," Proc. 2018 IEEE Int. Conf. Adv. Manuf. ICAM 2018, no. 1, pp. 202-205, 2019.

[7] H. Xie and X. Shi, "GIS-based tourism information system design and implementation," IC4E 2010 - 2010 Int. Conf. e-Education, e-Business, $e$ Management e-Learning, pp. 582-585, 2010.

[8] I. Sommerville, Software Engineering, 9th ed. Boston: Pearson Education, 2011.

[9] B. Unhelkar, Software Engineering with UML. Boca Raton: CRC Press, 2018.

[10] R. Elmasri and S. B. Navathe, Fundamentals of Database Systems Seventh Edition, 7th ed. Boston: Pearson, 2016.

[11] G. Developers, "Documentation Google Maps JavaScript API." [Online]. Available: https://developers.google.com/maps/documentation/jav ascript/tutorial. [Accessed: 17-Sep-2019]. 